\title{
ARBITRARILY PRIMED PCR FINGERPRINTING OF RNA AND DNA IN Entamoeba histolytica
}

\author{
Paulo Renato VALLE, Maria Betânia G. SOUZA, Edna M. PIRES, Edward F. SILVA \& Maria A. GOMES
}

\begin{abstract}
SUMMARY
Differences were detected in the gene expression of strains of $E$. histolytica using RNA (RAP-PCR) and DNA fingerprinting (RAPD). Analysis of the electrophoretic profiles of the gels revealed some polymorphic markers that could be used in the individual characterization of the strains. The 260 bands generated by using five different primers for RAP-PCR, as well as RAPD, were employed in the construction of dendograms. The dendogram obtained based on the RAPD products permitted the distinction of symptomatic and asymptomatic isolates, as well the correlation between the polymorphism exhibited and the virulence of the strains. The dendogram obtained for the RAP-PCR products did not show a correlation with the virulence of the strains but revealed a high degree of intraspecific transcriptional variability that could be related to other biological features, whether or not these are involved in the pathogenesis of amebiasis.
\end{abstract}

KEYWORDS: Entamoeba histolytica; Virulence; RAP-PCR; RAPD.

\section{INTRODUCTION}

The protozoan parasite Entamoeba histolytica, causative agent of amebiasis, produces very varied clinical manifestations, ranging from severe symptomatic presentations involving hepatic abscess to asymptomatic cases. This diversity in manifestations of the disease can be explained by the great variety of strains with different degrees of virulence. This variability of virulence is related to factors dependent on the host, the parasite and the interaction between the two of them. In relation to the parasite, many molecules related to this function have already been described ${ }^{1,2,3,5,7,8,9,12,13}$ and the mechanisms involved in destruction of the tissues elucidated to some extent. The process begins with adherence of the trophozoite to the target cell and is followed by cellular lysis, which may be preceeded by phagocytosis. The proteins that act in the diverse stages of this process, which ends in the destruction of the host cell, are present in a differentiated form in the diverse isolates of $E$. histolytica. Even so, the relationship between virulence of strains and variability of proteins is still not clear. In this study we analysed the gene expression of some strains of E. histolytica showing different degrees of virulence through the RAP-PCR (RNA Arbitrarily Primed PCR) technique ${ }^{21}$. This technique is carried out in two steps (cDNA synthesis and PCR) and provides a "fingerprinting" of RNA, enabling not only the identification of the products of gene expression, but also the intensity with which they are being transcribed. We can thus evaluate the real influence of a determined gene on the virulence of the strain at the moment of RNA extraction. We also analysed the DNA polymorphism of the strains in this study, using the RAPD (Randomly Amplified Polymorphic DNA) technique ${ }^{20}$, for comparison.

\section{MATERIALS AND METHODS}

\section{Strains of Entamoeba histolytica}

The strains of E. histolytica, culture conditions and some biological characteristics of the strains are summarized in Table 1.

\section{Nucleic acid extraction}

Axenic samples of E. histolytica were obtained from a culture in exponential growth phase. The trophozoites were washed with PBS pH 7.2 , concentrated by centrifugation at $300 \mathrm{~g}$ for $10 \mathrm{~min}$., counted and adjusted to $1 \times 10^{6}$ cells. Then, the DNA of these cells was digested with proteinase $\mathrm{K}$, extracted with phenol/chloroform and precipitated with ethanol ${ }^{14}$. The RNA was extracted by the TRIZOL $\AA$ method according to the manufacturer's protocol (Life-Technologies).

\section{cDNA preparation and RAP-PCR}

For cDNA synthesis we used the protocol described by WELSH et al. $(1992)^{21}$ with some modifications. Each $1 \mu \mathrm{g}$ of RNA was heated at $65^{\circ} \mathrm{C}$ for $10 \mathrm{~min}$. and the following reagents were added: $0.1 \mathrm{mM} \mathrm{dNTPs}$, 100 units of reverse transcriptase (Life-Technologies), $0.5 \mu \mathrm{g}$ of (oligo $\mathrm{dT}$ ), in a buffer that consisted of $50 \mathrm{mM}$ Tris/ $\mathrm{HCl}, \mathrm{pH} 8.3,50 \mathrm{mM} \mathrm{KCl}$, $3 \mathrm{mM} \mathrm{MgCl}_{2}$ and $10 \mathrm{mM}$ DTT in a final reaction volume of $20 \mu \mathrm{l}$. This mixture was incubated at $37{ }^{\circ} \mathrm{C}$ for 1 hour and $1 \mu \mathrm{g}$ of the resulting cDNA was employed in the PCR reaction. In this reaction $0.2 \mathrm{mM}$ of dNTPs and 1.0 unit of Taq DNA polymerase (Cenbiot, RS, Brazil) were 


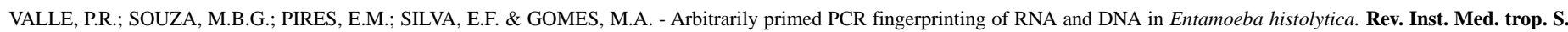
Paulo, 42(5): 249-253, 2000.

Table 1

E. histolytica strains used in this study

\begin{tabular}{|c|c|c|c|c|}
\hline strains & $\begin{array}{l}\text { clinical } \\
\text { form* }\end{array}$ & $\begin{array}{c}\text { culture } \\
\text { conditions }\end{array}$ & Virulence** & zymodeme \\
\hline HM1 & Sympt. & Axenic & $\begin{array}{c}\text { Amoebic abscess } \\
\text { Degree IV }\end{array}$ & Pathogenic \\
\hline CSP & Sympt. & Axenic & $\begin{array}{c}\text { Amoebic abscess } \\
\text { Degree IV }\end{array}$ & Pathogenic \\
\hline HK-9 & Sympt. & Axenic & $\begin{array}{c}\text { Amoebic abscess } \\
\text { Degree II }\end{array}$ & Pathogenic \\
\hline 200-NIH & Sympt. & Axenic & $\begin{array}{c}\text { Amoebic abscess } \\
\text { Degree II }\end{array}$ & Pathogenic \\
\hline 462 & Asympt. & Axenic & Negative & Pathogenic \\
\hline 452 & Asympt. & Axenic & Negative & Pathogenic \\
\hline 32 & Asympt. & Axenic & Negative & Pathogenic \\
\hline RPS & Asympt. & Axenic & Negative & Pathogenic \\
\hline
\end{tabular}

* Sympt. (symptomatic); Asympt. (asymptomatic).

** The virulence was determined by inoculation into hamster liver ${ }^{4}$. The inocula size variation was $5 \mathrm{x} 10^{3}$ to $1 \mathrm{x} 10^{6}$ amoebae.

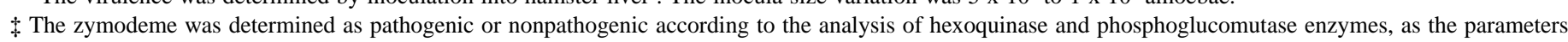
established by SARGEAUNT et al. $(1978)^{15}$.

used in a buffer that consisted of $10 \mathrm{mM}$ Tris- $\mathrm{HCl}, \mathrm{pH} 8.5,50 \mathrm{mM} \mathrm{KCl}$ and $1.5 \mathrm{mM} \mathrm{MgCl}_{2}$ in a final volume of $10 \mu \mathrm{l}$. One micromol of five different arbitrary primers was used in each amplification reaction. The samples were submitted to 1 cycle of $95^{\circ} \mathrm{C}$ for $1 \mathrm{~min}$., $40^{\circ} \mathrm{C}$ for $3 \mathrm{~min}$. and $72{ }^{\circ} \mathrm{C}$ for $3 \mathrm{~min}$., followed by 29 amplification cycles as follows: 95 ${ }^{\circ} \mathrm{C}$ for $1 \mathrm{~min}$., $55^{\circ} \mathrm{C}$ for $1 \mathrm{~min}$. and $72{ }^{\circ} \mathrm{C}$ for $2 \mathrm{~min}$.

\section{RAPD}

One nanogram of genomic DNA of each strain studied was used as a template for RAPD and as a control in the RAP-PCR reaction. The amplification reaction followed the protocol described by STEINDEL et al. $(1993)^{16}$. Each $10 \mu \mathrm{l}$ of the reaction mixture contained $0.8 \mathrm{U}$ of Taq DNA polymerase (Cenbiot-RS-Brazil), $0.2 \mathrm{mM}$ of dNTPs, $1.5 \mathrm{mM}$ of $\mathrm{MgCl}_{2}, 50 \mathrm{mM}$ of $\mathrm{KCl}, 10 \mathrm{mM}$ of Tris- $\mathrm{HCl}$ at $\mathrm{pH} 8.5$ and $1.0 \mu \mathrm{M}$ of primer. The following five primers were used in the two techniques:

\section{L1-5'a: 5'CGCTGGGAGCTGTAGACCGGAG, \\ L2401: 5'AATATCCACTTGCAGATTCTAG, \\ L15: 5'CTCCACCATTAGCACCCAAAGC, U2355: 5'GTGATGTGTGCATTCATCTCAT and $\lambda$ gt11: 5'TTGACACCAGACCAACTGGTAATG.}

Five microliters of the PCR products were run in 5\% polyacrylamide gel and stained with silver salts.

\section{Analysis of the RAP-PCR and RAPD data}

The data derived from the five primers, the DNA fragments (bands), were considered for analysis. The genetic distances between the strains were calculated by LINK et al. method $(1995)^{6}$ based on RAPD and RAP-PCR product. These distances were listed in two matrixes and used to construct dendograms. The LINK et al. method $(1995)^{6}$ provides the genetic distance through the following mathematical model: GDxy = $(\mathrm{Nx}+\mathrm{Ny}) /(\mathrm{Nx}+\mathrm{Ny}+\mathrm{Nxy})$ where $\mathrm{Nx}$ is the number of bands in line $\mathrm{x}$ and not in line $\mathrm{y}, \mathrm{Ny}$ is the number of bands in line $\mathrm{y}$ and not in line $\mathrm{x}$, and Nxy is the number of bands shared in lines $\mathrm{x}$ and $\mathrm{y}$. Tree topologies were established according to the clustering complete linkage method with the data presented on the matrixes. Once the complete linkage method works with cluster analysis, it considers the evolution rate as being the same for each strain, what makes the dendogram ultrameric. This means that the distance from the main root to the end of each branch is the same for each strain. The reason for using the complete linkage type of cluster analysis is that it allows the simultaneous comparison of intraspecific patterns. All the methods applied in the construction of dendograms, from the calculation of genetic distance to the designing of the trees, are part of the "TREECON for Windows" software package .

\section{RESULTS}

The cDNA and DNA extracted from all the strains were used as a template with five primers chosen at random. The products of the RAPPCR and the RAPD generated polymorphic patterns (Fig. 1). The polymorphism of bands and its philogenetical meaning are represented as numbers in the matrixes (Fig. 2) that lists the genetic distance between the strains calculated from RAPD and RAP-PCR data. The dendograms (Fig. 3) show a graphical idea of the information presented by the matrixes. The analysis of the tree based on the products of RAP-PCR did not present a correlation with the virulence of the strains (Fig. 3B). The analysis of the dendogram based on RAPD (Fig. 3A) revealed two groups, one formed by the strains isolated from symptomatic individuals and the other consisting of asymptomatic ones. The following ramifications corresponded to a greater or lesser virulence of the strains based on biological studies (Table 1). 

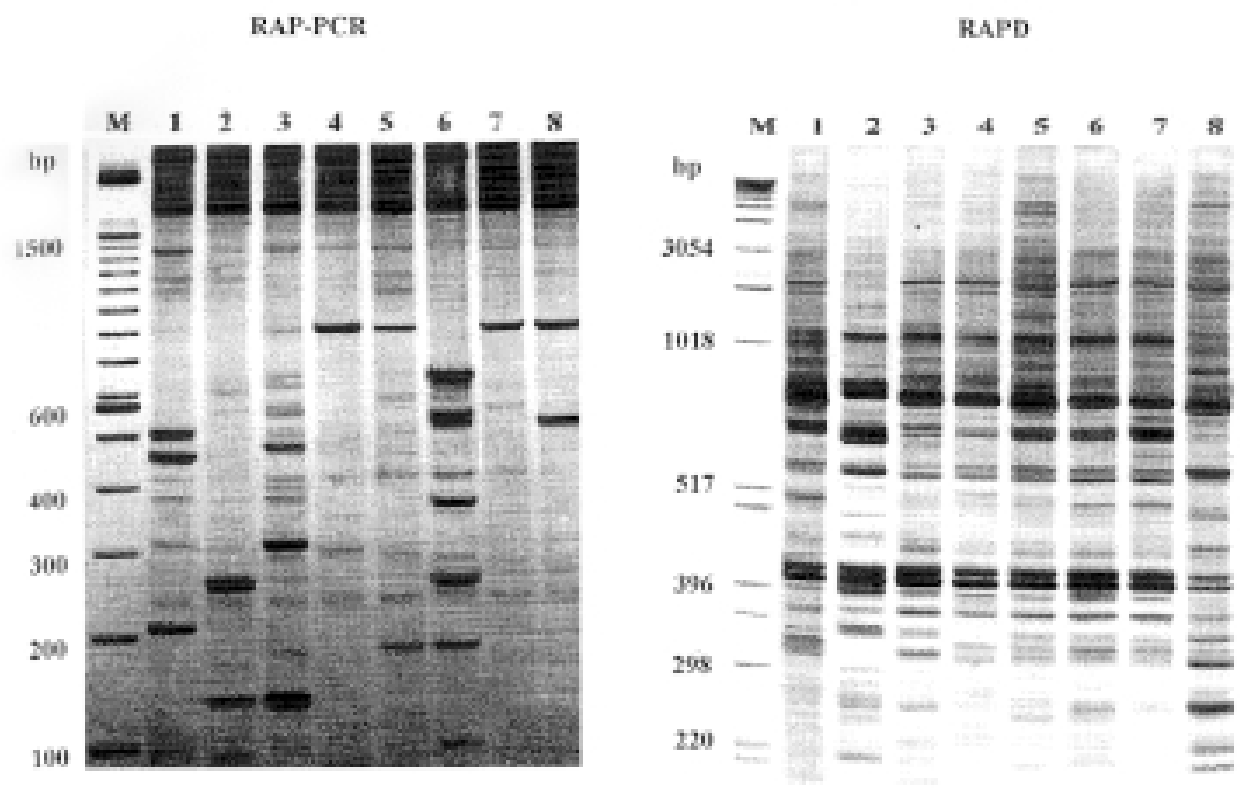

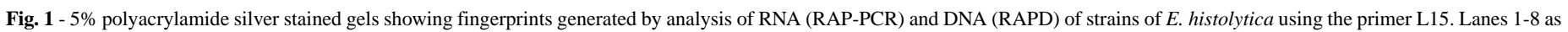
follows: HM1, CSP, HK-9, 200-NIH, 462, 452, RPS and 32.

\begin{tabular}{lcccccccc}
\hline \multicolumn{10}{c}{ RAPD matrix } \\
HM1 & HM1 & CSP & HK-9 & 200-NIH & $\mathbf{4 6 2}$ & $\mathbf{4 5 2}$ & RPS & $\mathbf{3 2}$ \\
CSP & 0.000 & 50.714 & 53.472 & 57.500 & 52.632 & 56.494 & 57.407 & 61.392 \\
HK-9 & 50.714 & 0.000 & 59.627 & 57.059 & 51.553 & 53.416 & 56.140 & 57.317 \\
NIH-200 & 53.472 & 59.627 & 0.000 & 43.949 & 46.497 & 43.421 & 52.381 & 60.355 \\
$\mathbf{4 6 2}$ & 57.500 & 57.059 & 43.949 & 0.000 & 37.736 & 33.333 & 45.930 & 50.296 \\
$\mathbf{4 5 2}$ & 52.632 & 51.553 & 46.497 & 37.736 & 0.000 & 26.897 & 35.849 & 47.239 \\
RPS & 56.494 & 53.416 & 43.421 & 33.333 & 26.897 & 0.000 & 24.490 & 44.304 \\
$\mathbf{3 2}$ & 57.407 & 56.140 & 52.381 & 45.930 & 35.849 & 24.490 & 0.000 & 37.975 \\
\hline
\end{tabular}

\begin{tabular}{lcccccccc}
\hline \multicolumn{10}{c}{ RAP-PCR matrix } \\
HM1 & HM1 & CSP & HK-9 & 200-NIH & $\mathbf{4 6 2}$ & $\mathbf{4 5 2}$ & RPS & $\mathbf{3 2}$ \\
CSP & 0.000 & 47.771 & 40.000 & 52.703 & 46.104 & 49.359 & 57.246 & 64.000 \\
HK-9 & 47.771 & 0.000 & 51.786 & 48.507 & 48.980 & 53.333 & 53.226 & 58.955 \\
NIH-200 & 40.000 & 51.786 & 0.000 & 52.903 & 48.466 & 48.765 & 63.816 & 66.250 \\
$\mathbf{4 6 2}$ & 52.703 & 48.507 & 52.903 & 0.000 & 56.429 & 54.745 & 53.636 & 60.000 \\
$\mathbf{4 5 2}$ & 46.104 & 48.980 & 48.466 & 56.429 & 0.000 & 47.552 & 56.000 & 63.504 \\
RPS & 49.359 & 53.333 & 48.765 & 54.745 & 47.552 & 0.000 & 50.420 & 50.420 \\
$\mathbf{3 2}$ & 57.246 & 53.226 & 63.816 & 53.636 & 56.000 & 50.420 & 0.000 & 51.515 \\
\hline
\end{tabular}

Fig. 2 - Quadratic and symmetric matrixes of genetic distances calculated between strains of Entamoeba histolytica. 


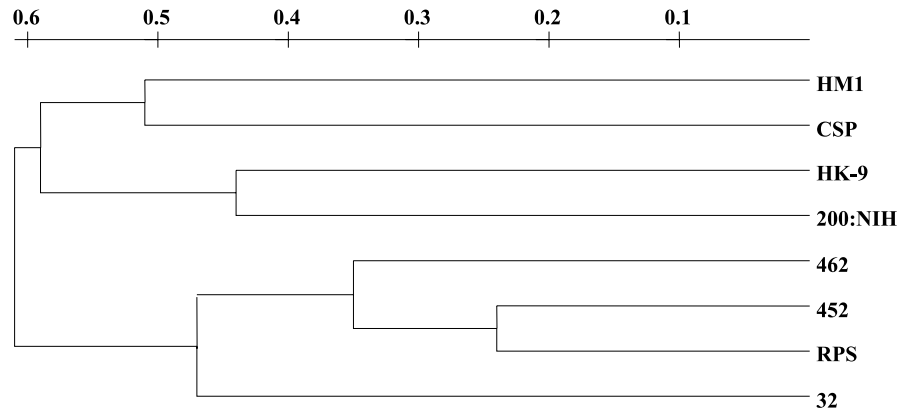

RAPD

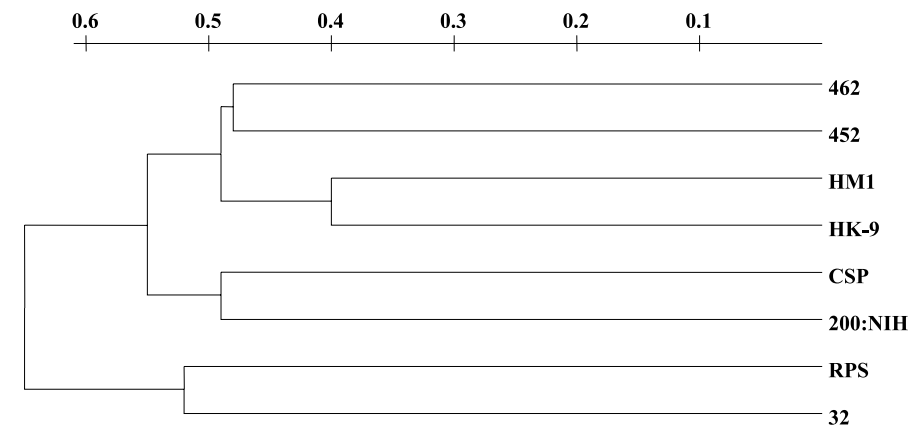

RAP-PCR

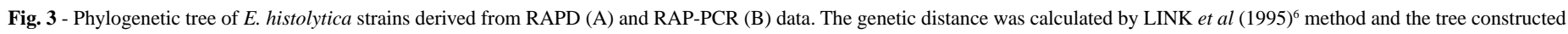
by clustering complete linkage method ${ }^{19}$.

\section{DISCUSSION}

The protozoan parasite E. histolytica possesses an exceptional capacity for tissue destruction that can be considered as its principal pathogenic characteristic ${ }^{11}$. This capacity, however, is not found in all isolates. The identification and characterization of the molecular bases involved in its cytotoxicity have been sought, and several molecules were discovered as responsible for this function ${ }^{1,7,8,9,13}$. Different amebae molecules, have been found in virulent strains, being present at lower levels or even absent in strains presenting low virulence $e^{2,3,5,12,17,19}$. Considerable diversity has also been found in the genes that code for some of these proteins ${ }^{10}$. Nevertheless, there is no clear correlation between this protein diversity and the capacity to produce tissue damage.

In view of the above we sought to evaluate the virulence of $E$. histolytica using the RAP-PCR technique as an approach to the differentiation of genes expression. We compared the results obtained with this method with the well-established RAPD technique. It was believed that the results obtained using RAP-PCR with arbitrary primers, capable of evaluating RNA variability, would be more indicative of the virulence of the strains, since this technique analyses the product of gene transcription, determining the phenotype of the strains, and would thus presumably be more sensitive.

The variability of RNA and DNA was analysed using dendograms and a greater variability in the RNA was observed with the primers employed here. However, this greater variability did not correlate with the virulence of the strains. On the contrary, the DNA polymorphism visualized by RAPD revealed a better concordance with strain virulence. These results suggest that, at least with the primers used, RAPD may have amplified neutral regions of the DNA of the samples that in their phylogenetically conserved form did not suffer pressures of axenic culture or prolonged manipulation in the laboratory. By contrast, RAP-PCR should have amplified individual-specific regions, revealing the great protein variability within the species. These differentially amplified regions may constitute important molecules involved in the pathogenesis of amebiasis or could be the result of mutations due to prolonged maintenance in the laboratory, and may thus constitute important potential targets for the understanding of the still-obscure aspects of the biology of this parasite. Nevertheless, the RAP-PCR analysis did not differentiate between symptomatic and asymptomatic strains, as did the RAPD one.

\section{RESUMO}

\section{Impressões digitais de DNA e RNA através de AP-PCR em Entamoeba histolytica}

Diferenças na expressão gênica de cepas de E. histolytica foram obtidas pelo "fingerprinting" de RNA (RAP-PCR) e DNA (RAPD). A análise do perfil eletroforético do gel revelou alguns marcadores polimórficos que poderiam ser usados na caracterização individual das cepas. As 260 bandas geradas pela utilização de cinco primers diferentes, tanto no RAP-PCR, quanto no RAPD foram empregadas na construção de dendogramas. O dendograma obtido com os produtos do RAPD permitiu a distinção das cepas isoladas de pacientes sintomáticos e assintomáticos, além de correlacionar o polimorfismo exibido com a virulência das mesmas. O dendograma obtido com os produtos do RAPPCR não apresentou correlação com a virulência das cepas, mas revelou uma exuberante variabilidade transcricional intra-específica, que pode estar relacionada a outros caracteres biológicos envolvidos, ou não, na patogênese da amebíase.

\section{ACKNOWLEDGMENTS}

This work was supported with grants from CNPq and FAPEMIG.

\section{REFERENCES}

1. ANDRÄ, J. \& LEIPPE, M. - Pore-forming of Entamoeba histolytica. Significance of positively charged aminoacids residues for its mode of action. FEBS Lett., 354: 97 102,1994

2. GOMES, M.A.; MELO, M.N.; PESQUERO, J.L. \& SILVA, E.F. - Characterization for virulence of an axenic strain of Entamoeba histolytica: evidence for overexpression of two proteins. Arch. med. Res., 28: 489-492, 1997. 

Paulo, 42(5): 249-253, 2000.

3. GONZALES-RUIZ, A.; HAQUE, R.; REHMAN, T. et al. - A monoclonal antibody for distinction of invasive and non invasive clinical isolates of Entamoeba histolytica. J. clin. Microbiol., 30: 2807-2813, 1992.

4. JARUMILINTA, R. \& MAEGRAITH, B. - Enzymes of Entamoeba histolytica. Bull. Wld. Hlth. Org., 41: 269-273, 1961.

5. LEIPPE, M. - Amoebapores. Parasit. today, 13: 178-183, 1997.

6. LINK, W.; DIXKENS, C.; SINGH, M.; SCHWALL, M. \& MELCHINGER, A.E. - Genetic diversity in European and Mediterranean faba bean germ plasm revealed by RAPD markers. Theoret. appl. Genet., 90: 27-32, 1995.

7. LÓPEZ-REVILLA, R.; JIMÉNEZ-DELGADILLO, B.; CANTO-ORTIZ, L. \& CHÁVEZDUEÑAS, L. - Variation of proteins and proteinases in Entamoeba histolytica lysates containing a protease inhibitor. Arch. med. Res., 23: 87-89, 1992.

8. LUSHBAUGH, W.B.; HOFBAUER, A.F.; KAIRALlA, A.A.; CANTEY, J.R. \& PITTMAN, F.E. - Relationship of cytotoxin of axenically cultivated Entamoeba histolytica to virulence. Gastroenterology, 86: 1488-1495, 1984.

9. MIRELMAN, D.; KEREN, Z. \& BRACHA, R. - Cloning and partial characterization of an antigen detected on membrane surfaces of non-pathogenic strains of Entamoeba histolytica. Arch. med. Res., 23: 49-53, 1992.

10. QUE, X. \& REED, S.L. - The role of extracellular cysteine proteinase in pathogenesis of Entamoeba histolytica invasion. Parasit. today, 13: 190-194, 1997.

11. RAVDIN, J.L. - Amebiasis. Clin. infect. Dis., 20: 1453-1466, 1995.

12. REED, S.L.; BOUVIER, J.; HIRATA, K. et al. - A unique cysteine proteinase gene of pathogenic Entamoeba histolytica correlates with virulence. Arch. med. Res., 23: 181-182, 1992.
13. RIGOTHIER, M.C.; GARCÍA-RIVERA, G.; GUADERRAMA, M. \& OROZCO, E. Purification and functional characterization of the $112 \mathrm{kDa}$ adhesin of Entamoeba histolytica. Arch. med. Res., 23: 239-241, 1992.

14. SAMBROOK, J.; FRITSCH, E.F. \& MANIATIS, T. - Molecular cloning. A laboratory manual. 2 ed. New York, Cold Spring Harbor Laboratory Press, 1989.

15. SARGEAUNT, P.G.; WILLIAMS, J.E. \& GRENE, J.D. - The differentiation invasive and non-invasive Entamoeba histolytica by isoenzyme Trans. roy. Soc. trop. Med. Hyg., 72: 519-521, 1978

16. STEINDEL, M.; DIAS NETO, E.; MENEZES, C.L.P.; ROMANHA, A.J. \& SIMPSON, A.J.G. - Random amplified polymorphic DNA analysis of Trypanosoma cruzi strains. Molec. biochem. Parasit., 60: 71-79, 1993.

17. TORIAN, B.E.; REED, S.L.; FLORES, B.M. et al. - The 96-kilodalton-antigen as an integral membrane protein in pathogenic Entamoeba histolytica: potential differences in pathogenic and nonpathogenic isolates. Infect. Immun., 58: 753-760, 1990.

18. VAN DE PEER, Y. \& DE WACHTER, R. - TREECON for Windows: a software package for the construction and drawing of evolutionary trees for the Microsoft Windows environment. Comput. appl. Biosci., 10: 569-570, 1994.

19. VARGAS, M.A. \& OROZCO, E. - Entamoeba histolytica: changes in the zymodeme of cloned nonpathogenic trophozoites cultured under different conditions. Parasit. Res. 79: 353-356, 1993.

20. WELSH, J. \& McCLELLAND, M. - Fingerprinting genomes using PCR with arbitrary primers. Nucleic Acids Res., 18: 7213-7218, 1990

21. WELSH, J.; CHADA, K.; DALAL, S.S. et al. - Arbitrarily primed PCR fingerprinting of RNA. Nucleic Acids Res., 20: 4965-4970, 1992.

Received: 13 March 2000

Accepted: 29 June 2000 